\title{
Developing and Testing a Best Practice Framework for Energy Access Interventions
}

Chen, Xiaoxiao; Narkeviciute, Rasa; Haselip, James Arthur; Mackenzie, Gordon A.

Published in:

Sustainable Development

Link to article, DOI:

$10.1002 / \mathrm{sd} .1583$

Publication date:

2015

Document Version

Peer reviewed version

Link back to DTU Orbit

Citation (APA):

Chen, X., Narkeviciute, R., Haselip, J. A., \& Mackenzie, G. A. (2015). Developing and Testing a Best Practice Framework for Energy Access Interventions. Sustainable Development, 23(5), 257-272. https://doi.org/10.1002/sd.1583

\section{General rights}

Copyright and moral rights for the publications made accessible in the public portal are retained by the authors and/or other copyright owners and it is a condition of accessing publications that users recognise and abide by the legal requirements associated with these rights.

- Users may download and print one copy of any publication from the public portal for the purpose of private study or research.

- You may not further distribute the material or use it for any profit-making activity or commercial gain

- You may freely distribute the URL identifying the publication in the public portal 


\title{
Developing and testing a Best Practice framework for Energy Access Interventions
}

\author{
Xiaoxiao Chen, Rasa Narkeviciute, James Haselip and Gordon Mackenzie \\ UNEP DTU Partnership, Department of Management Engineering, \\ UN City, Marmorvej 51, 2100 Copenhagen Ø, Denmark
}

Keywords: energy access; best practice; indicators; geometric aggregation

\begin{abstract}
This article presents an attempt to operationalize the concept of "best practice", as applied to project-based interventions to expand energy access in developing countries. To this end a methodology has been developed to quantify project performance across five dimensions, each informed by three key indicators, and aggregate these into a composite indicator, using weights obtained from a survey of experts. The experience demonstrates the inherent limitations in developing a 'one-size-fits-all' methodology, revealing the implicit tension between the political desire to refer to objective, absolute, measures of best practice vs. highly contextual realities where baselines are often lacking. However the methodology does offer a comparative means to highlight the relative strengths and weaknesses of any given project, enabling both ex-post assessments and project learning. The study features an analysis of cases selected from the Energy Access Knowledge Base, published by the Global Network of Energy for Sustainable Development (GNESD).
\end{abstract}

\section{Introduction}

\subsection{Energy access and the need for understanding 'best practice' interventions}

There is no widely agreed upon definition of what constitutes 'energy access'. In order to achieve universal access to modern energy services by 2030, the IEA (Jones, 2010) has proposed $100 \mathrm{kWh}$ of electricity and $100 \mathrm{~kg}$ of modern fuels per person per year as a minimum 'threshold' for defining energy access. However, in reality this translates into little 
more than the use of electric light and a few low-watt appliances such as radios and mobile phone chargers. In order to reap the more significant development benefits of electrification, households need to use refrigerators and labour-saving devices such as washing machines, vacuums and food processors which imply far higher consumption levels (the global average was just over 3,000 kWh per capita per year in 2011). Furthermore, Practical Action (Practical Action, 2012) proposes Total Energy Access standards covering five energy services: lighting, cooking and water heating, space heating, cooling, and information and communication with specific numerical standards.

In this paper we follow the simplified definition put forward by the Global Energy Assessment (GEA), where the pursuit of universal access to modern energy is divided into two aspects: the availability of modern energy carriers ${ }^{1}$ (i.e. electricity) and the availability of improved end-use appliances (i.e. cook stoves) at an affordable price, with no fixed quantitative targets/standards (GEA, 2012).

While most developed countries pay more attention to their domestic energy security or energy mix, the rural poor in developing countries are still facing the challenges of energy poverty. Currently, less than $68 \%$ of the rural population in developing countries has access to electricity (Birol, 2010). The overall average electrification rate in sub-Saharan Africa (SSA) is $24 \%$ compared to $40 \%$ in non-African low-income countries. In terms of generation capacity, the total of all SSA countries (48) is around $28 \mathrm{GW}$, less than that of Argentina. Furthermore, over three billion people are dependent primarily on traditional solid fuels (GEA, 2012). There is a well-established academic literature on how energy access can reduce poverty and empower rural development in direct and indirect ways and the importance of access to modern energy is well recognized by the global community (Ostojic et al., 2011; UNDP, 2012; UNDP, 2011; Practical Action, 2010). While numerous studies have sought to develop assessment criteria for project-level interventions aimed at increasing energy access, there has been no attempt to develop and apply the concept of "best practice" to energy access interventions. The concept of "best practice" has been applied in numerous fields and is often derided for being used as little more than a buzzword by development

\footnotetext{
${ }^{1}$ Primary energy carriers can be explained as an input to the appliances that produce the energy services in this report: i) Electricity: provided by a grid, stand-alone generation or battery supply; ii): Fuel: in solid, liquid or gaseous states that are combusted in appliances in order to deliver the energy service (UNDP, 2012).
} 
practitioners and policy makers. At the most basic level, best practice is a means to evaluate the performance or outcome of a specific programme, activity, strategy or method (CCF, no date). However, a diversity of related concepts and terms has emerged including successful practice, good practice, promising practice and smart practice. These vary is their degree of 'hard' criteria-backed assessments, with some based on little more than "initial evidence of effectiveness" (Snyder et al., 2012) or expert opinions regarding 'what works'. Most of these terms imply relative measures, whereas best practice can be both relative and absolute, when measured against a pre-defined 'ideal' scenario. Either way, best practice strives towards standardization, especially in management practices, and is commonly defined as the most efficient and effective means to accomplish a task or achieving a goal (Paul, 2008). Indeed the benchmarking aspect of 'best practice' likely explains its strong political currency and popularity.

In this article we present an attempt to develop and apply a measure of best practice, where specific energy access interventions (projects) are assessed against the best possible outcome. The application of best practice can be seen as a form of measurement and reporting, which are recognised as essential components in efforts to accomplish universal modern energy access and support policy making (Bazilian et al., 2010). In turn, the procedure of monitoring and reporting progress towards improving energy access is instrumental for public accountability (Birol and Brew-Hammond, 2012) and (Fransen et al., 2008) point out that a robust measuring and reporting mechanism will help in:

- Improving the availability of information about the range and impacts of actions that countries are taking to increase access to energy

- Helping countries clearly delineate and monitor actions they can take to meet their agreed target

- Increasing awareness among countries of policy options and best practice

- Enhancing the effectiveness of implementation of such policies at national and local levels, and the credibility of all countries' efforts

ESMAP's energy access report (ESMAP, 2012) integrates the concept of "best practice” into the provision of access to clean energy for the urban poor in four countries and evaluates various cases to identify common barriers and highlights options to overcome them. Though 
ESMAP provides lessons to scale up and accelerate the implementation of these energy access interventions for further study, it does not include a comprehensive framework or approach to measure energy access cases and to identify "best practice" in rural areas, which is the focus on this article.

In conclusion, we note that the concept of "best practice" is useful for maintaining the momentum of ensuring universal energy access for all. The concept of "best practice" in this study represents a valuable concept for qualifying the performance of energy access interventions. That is, it could track, measure and report interventions that expand access to modern energy services.

\subsection{Characterizing, Measuring and Evaluating Energy Access Interventions}

A considerable body of literature exists on energy access, mostly focusing on case studies that provide relevant lessons and principles (Jones, 2010; Ostojic et al., 2011; Birol and Brew-Hammond, 2012; Joseph, 2011; IEA, 2011; ESMAP, 2012; Ekouevi and Tuntivate, 2011; Practical Action, 2009). The UNDP (UNDP, 2010) clarifies the role of universal clean energy access in achieving the MDGs, highlighting the importance of "strengthening national policy and institutional frameworks; mobilizing financing options; developing effective approaches for scaling up delivery at the local level”. In addition, the World Bank's Africa Renewable Energy and Access Programme (AFREA) provides lessons related to household energy access, such as the importance of public awareness campaigns as a prerequisite for successful interventions, that improved stoves users' needs and preferences should be given priority, and that in order to disseminate household energy access the durability of technology is a key factor (UNDP, 2010).

By reviewing available literature it is difficult to isolate, aggregate and integrate the main energy access interventions to inform the concept of "best practice". In addition, a simple but effective evaluation and measurement approach for energy access is currently missing (Ilskog, 2008) though there have been numerous attempts to conduct comprehensive measurements on energy access as opposed to expanding energy access interventions (Practical Action, 2012; Practical Action, 2010; SE4ALL, 2012; Gómez and Silveira, 2010; IEA, 2012). We pursue a concept of "best practice" to provide a relative measure of interventions rather than the absolute degree of energy access achieved. As such, we develop an in-depth 
parameterized evaluation methodology to address these issues, providing decision makers with a tool to track the performance of energy access interventions.

A number of studies provide guidance for the design of metrics, both within and outside the field of energy access. Possible metrics for measuring and reporting on energy access include: single indicator, dashboard of indicators, composite index and multi-tier. In this study, we seek to combine information across several different dimensions into values that can be compared and analysed. Therefore it seems appropriate to use a composite indicator. Composite indicators have proven to be convenient in benchmarking or monitoring performance and setting policy priorities (OECD and JRC, 2008), despite certain shortcomings that arise from the need to make assumptions and simplifications that building composite indicators requires (Bazilian et al., 2010 offers a good discussion).

Following these observations, we set ourselves a two-stage goal for this study:

1. to operationalise the concept of best practice as applied to project-based interventions that seek to expand energy access in developing countries, and

2. to build a composite index for qualifying and comparing the performance of energy access interventions within the best practice framework.

To illustrate the functionality of the index, we conduct an example valuation of Energy Access Interventions using several real-life case studies. The testing of the method is based mainly on the publicly available information in the Global Network of Energy for Sustainable Development's (GNESD) Energy Access Knowledge Base (GEAKB) (GNESD, 2013b).

In the next section we present the proposed "best practice" framework and the methodology used to build a composite indicator for measuring the performance of energy access interventions. The case studies are presented in Section 3.

\section{Methodology}

In this section we present the concept of "best practice" that we apply in evaluating energy access interventions (EAIs), defining a multi-dimensional framework for measuring the 
quality of EAIs corresponding to electrification and modern cooking solutions. Integrating this concept of "best practice", we then develop the composite index for EAIs, used to characterize and measure their impacts. The process of development for the index consisted of several iterations, but it can broadly be divided into the following steps (OECD and JRC, 2008):

1. Theoretical framework

2. Selection of indicators

3. Evaluation of indicator performance

4. Weighting

5. Aggregation

6. Visualisation

\subsection{Theoretical framework}

Compounding the difficulty of understanding energy access is the wide range of factors involved in energy access interventions. Therefore, it is helpful to divide the performance of energy access interventions into different dimensions (or areas), which all play a role in the integral performance of a given intervention. Before we attempt to obtain an objective and reasonable measurement and evaluation of energy access interventions, we analyse the dimensionality of these interventions.

Previous studies have mostly focused on a single dimension of the energy access issue, such as adequacy (or availability above a minimum threshold quantity), physical availability of energy carriers, affordability, quality and reliability (Pachauri, 2011). Meanwhile, other work has translated definitions of sustainable development into the provision of modern energy services terms (IAEA, 2005). Most models provide a specific perspective by focusing on particular objectives. Building upon the integration of sustainable development with energy access issues, Shyu (2010) categorized four aspects to analyse the implementation of the Township Electricity Programme in China: technical, financial, human resource, and institutional (Shyu, 2010).

Based on a select literature review of energy access programmes from multi-dimensional approaches (Bhattacharyya, 2012a; Ilskog, 2008; Ilskog and Kjellström, 2008; Yadoo and 
Cruickshank, 2012; Bhattacharyya, 2012b; Fuso Nerini et al., 2014) , we find most of the assessments have in fact used five dimensions: technical, economic, social, environmental, and organisational/institutional/political. Due to the close linkage between institutional, organisational and political dimensions, in our study we propose to merge them into one overarching dimension "political”. In addition, in the sustainable development context, it is beneficial to focus on overall financing framework of activities within the initiative and its ability to remain sustained beyond the time horizon of the initiative itself. Therefore, in this study, we propose to use a "financial" dimension which focuses only on access to project financing, and not on the project costs of the initiatives themselves. In short, we propose to use five assessment dimensions in this study: social, political, financial, technical, and environmental. We assume that these areas are equally important.

\subsection{Selection of indicators}

Following on from the five dimensions identified for the assessment tool, this section aims to set and assign well-defined indicators. While a number of indicators have been suggested in the past for assessing energy access, a greater number of indicators does not necessarily result in better measurement and reporting (Bhattacharyya, 2012a). On the contrary, the evaluation and assessment processes are simplified and more operational if a manageable set of relevant indicators is employed. Firstly, it is necessary to avoid overlaps and redundancy in an indicator list. We aimed to create a set of indicators that would be easy to understand and specific, but at the same time flexible enough to be adapted to the various interventions. These principles in indicator selection are needed to ensure that the resulting tool is robust and suitable to evaluating EAIs from the "best practice" perspective. The proposed set of indicators is shown in Table 1.

We draw upon both qualitative and quantitative indicators. Quantitative indicators are used to measure phenomena that lend themselves to numerical information, such as GHG emissions and job creation. Qualitative indicators are mainly used for determining the level of progress towards a specific goal, based upon narrative findings from case studies that are subject to differing perspectives, rather than objective measures. For example it is difficult to select a quantitative indicator of public attitude since the term itself is highly subjective.

\subsection{Evaluation of indicator performance}


The resulting composite indicator should be applicable in the evaluation of past and future interventions. This means that it should be easy to use and require as little extra resources as possible. For this reason we propose the use expert judgement to evaluate all indicators, on the same scale. This achieves two benefits: first, it does not require any complex and costly quantitative data collection, and secondly, the data does not require further processing in terms of normalisation. This also fits well with the original purpose of the study to make sure that the indicator reflects the best practice concept. 
Table 1: Indicator evaluation table

\begin{tabular}{|c|c|c|c|c|c|c|}
\hline Dimension & Indicator (description) & Value (state of indicator) & & & & \\
\hline $\mathrm{J}$ & $\mathrm{i}$ & 1 (very poor) & 2 (poor) & 3 (fair) & 4 (good) & 5 (very good) \\
\hline \multirow[t]{3}{*}{ Social } & $\begin{array}{l}1 \text { Social } \\
\text { progress/benefit in } \\
\text { local community and } \\
\text { region from an } \\
\text { intervention }\end{array}$ & $\begin{array}{l}\text { Social regress in local } \\
\text { community and region } \\
\text { caused by the intervention }\end{array}$ & $\begin{array}{l}\text { No social } \\
\text { progress/benefit in } \\
\text { local community and } \\
\text { region from the } \\
\text { intervention }\end{array}$ & $\begin{array}{l}\text { Low social progress/benefit } \\
\text { in local community and } \\
\text { region from the intervention }\end{array}$ & $\begin{array}{l}\text { Medium social progress/benefit } \\
\text { in local community and region } \\
\text { from the intervention }\end{array}$ & $\begin{array}{l}\text { Considerable social } \\
\text { progress/benefit in local } \\
\text { community and region from } \\
\text { the intervention }\end{array}$ \\
\hline & $\begin{array}{l}2 \text { Contribution to local } \\
\text { productive } \\
\text { activities/job creation }\end{array}$ & $\begin{array}{l}\text { Intervention decreases } \\
\text { employment and/or hinders } \\
\text { inhabitants' capacity to } \\
\text { engage in productive } \\
\text { activities }\end{array}$ & $\begin{array}{l}\text { No contribution to } \\
\text { create jobs or local } \\
\text { productive activities }\end{array}$ & $\begin{array}{l}\text { The intervention has a } \\
\text { limited contribution to create } \\
\text { jobs, improves a few local } \\
\text { productive activities, but it } \\
\text { does not create new } \\
\text { productive activities }\end{array}$ & $\begin{array}{l}\text { The intervention contributes to } \\
\text { job creation, improves local } \\
\text { productive activities, but it does } \\
\text { not create new productive } \\
\text { activities }\end{array}$ & $\begin{array}{l}\text { The intervention contributes } \\
\text { to job creation, improves } \\
\text { local productive activities } \\
\text { and creates new productive } \\
\text { activities }\end{array}$ \\
\hline & $\begin{array}{l}3 \text { Public attitude to the } \\
\text { intervention }\end{array}$ & $\begin{array}{l}\text { Public against the } \\
\text { intervention, and the } \\
\text { intervention has negative } \\
\text { effects on social justice } \\
\text { and harmony }\end{array}$ & $\begin{array}{l}\text { Public have poor } \\
\text { opinion toward the } \\
\text { intervention and its } \\
\text { effects on society }\end{array}$ & $\begin{array}{l}\text { Public have no opinion } \\
\text { toward the intervention or its } \\
\text { effects on society }\end{array}$ & $\begin{array}{l}\text { Public have good opinion toward } \\
\text { the intervention and its effects on } \\
\text { society }\end{array}$ & $\begin{array}{l}\text { Public have excellent opinion } \\
\text { toward the intervention and } \\
\text { its effects on society }\end{array}$ \\
\hline \multirow[t]{3}{*}{ Political } & $\begin{array}{l}1 \text { Political environment } \\
\text { and energy targets }\end{array}$ & $\begin{array}{l}\text { No reference to energy } \\
\text { access in national/regional } \\
\text { policy }\end{array}$ & $\begin{array}{l}\text { Little reference to } \\
\text { energy access in the } \\
\text { Poverty Reduction } \\
\text { Strategy or other } \\
\text { flagship policy }\end{array}$ & $\begin{array}{l}\text { National/Regional policy has } \\
\text { references to Energy Access } \\
\text { but no clear targets }\end{array}$ & $\begin{array}{l}\text { National/Regional policy has } \\
\text { specific energy targets that } \\
\text { include electricity, household } \\
\text { cooking, health centres/school } \\
\text { and enterprise }\end{array}$ & $\begin{array}{l}\text { As "3 (good)", with good } \\
\text { evidence of secondary } \\
\text { legislation to deliver targets }\end{array}$ \\
\hline & $\begin{array}{l}2 \text { Effective local } \\
\text { energy institution or } \\
\text { equivalent }\end{array}$ & $\begin{array}{l}\text { No institution involvement } \\
\text { in the expansion of energy } \\
\text { access intervention }\end{array}$ & $\begin{array}{l}\text { Lack of clarity on } \\
\text { which institution (or no } \\
\text { institution) is leading } \\
\text { on energy access to } \\
\text { rural areas }\end{array}$ & $\begin{array}{l}\text { Rural energy institution or } \\
\text { equivalent has been } \\
\text { mandated, but is under- } \\
\text { resourced or shows limited } \\
\text { progress on improved access }\end{array}$ & $\begin{array}{l}\text { Rural energy institution or } \\
\text { equivalent has been mandated, } \\
\text { has appropriate resources and } \\
\text { shows progress on improved } \\
\text { access. }\end{array}$ & $\begin{array}{l}\text { As "3 (good)" and on track } \\
\text { towards national/regional } \\
\text { energy access targets }\end{array}$ \\
\hline & $\begin{array}{l}3 \text { Transparent and } \\
\text { accountable multi- } \\
\text { stakeholder process } \\
\text { utilized in current } \\
\text { policy formulation }\end{array}$ & $\begin{array}{l}\text { Process information of the } \\
\text { intervention is unavailable }\end{array}$ & $\begin{array}{l}\text { No formal procedure } \\
\text { for transparent and } \\
\text { accountable processes }\end{array}$ & $\begin{array}{l}\text { Formal procedures for } \\
\text { transparent and accountable } \\
\text { processes in place, but not } \\
\text { used by all stakeholders }\end{array}$ & $\begin{array}{l}\text { Transparent and accountable } \\
\text { processes used by all } \\
\text { stakeholders, with transparent } \\
\text { information systems and } \\
\text { accountable relationships, with } \\
\text { internal recognition }\end{array}$ & $\begin{array}{l}\text { Widespread external } \\
\text { recognition of transparent } \\
\text { and accountable processes } \\
\text { used by all stakeholders, with } \\
\text { transparent information } \\
\text { systems and accountable } \\
\text { relationships }\end{array}$ \\
\hline Financial & $\begin{array}{l}1 \text { Co-financing } \\
\text { structure }\end{array}$ & $\begin{array}{l}\text { No specific } \\
\text { national/regional energy } \\
\text { access budget or private } \\
\text { sector investments }\end{array}$ & $\begin{array}{l}\text { National/ regional } \\
\text { energy access budget } \\
\text { and private sector } \\
\text { investments are static }\end{array}$ & $\begin{array}{l}\text { National/ regional energy } \\
\text { access budget and private } \\
\text { sector investments are } \\
\text { increasing but not sufficient } \\
\text { to deliver access targets }\end{array}$ & $\begin{array}{l}\text { National/ regional energy access } \\
\text { budget and private sector } \\
\text { investments are increasing and } \\
\text { will help to deliver access targets }\end{array}$ & $\begin{array}{l}\text { National/ regional energy } \\
\text { access budget and private } \\
\text { sector investments are } \\
\text { delivering access target with } \\
\text { evidence of good progress }\end{array}$ \\
\hline
\end{tabular}




\begin{tabular}{|c|c|c|c|c|c|c|}
\hline & $\begin{array}{l}2 \text { Proportion of } \\
\text { combination of end- } \\
\text { user financing }\end{array}$ & $\begin{array}{l}\text { No financing mechanism } \\
\text { of end user }\end{array}$ & $\begin{array}{l}\text { Minimal proportion of } \\
\text { combination of active } \\
\text { end-user financing } \\
\text { mechanism } \\
\text { corresponding to local } \\
\text { appropriate financing } \\
\text { options }\end{array}$ & $\begin{array}{l}\text { Small and static proportion } \\
\text { of combination of end-user } \\
\text { financing mechanism } \\
\text { corresponding to local } \\
\text { appropriate financing options }\end{array}$ & $\begin{array}{l}\text { A growing proportion of } \\
\text { combination of end-user } \\
\text { financing mechanism } \\
\text { corresponding to local } \\
\text { appropriate financing options }\end{array}$ & $\begin{array}{l}\text { A high proportion of } \\
\text { combination of end-user } \\
\text { financing mechanism } \\
\text { corresponding to local } \\
\text { appropriate financing options }\end{array}$ \\
\hline & $\begin{array}{l}3 \text { Sustainable financing } \\
\text { mechanism }\end{array}$ & $\begin{array}{l}\text { No specific } \\
\text { national/regional energy } \\
\text { access budget or private } \\
\text { sector investments }\end{array}$ & $\begin{array}{l}\text { National/ regional } \\
\text { energy access budget } \\
\text { and private sector } \\
\text { investments are static }\end{array}$ & $\begin{array}{l}\text { National/ regional energy } \\
\text { access budget and private } \\
\text { sector investments are } \\
\text { increasing but not sufficient } \\
\text { to deliver access targets }\end{array}$ & $\begin{array}{l}\text { National/ regional energy access } \\
\text { budget and private sector } \\
\text { investments are increasing and } \\
\text { will help to deliver access targets }\end{array}$ & $\begin{array}{l}\text { National/ regional energy } \\
\text { access budget and private } \\
\text { sector investments are } \\
\text { delivering access target with } \\
\text { evidence of good progress }\end{array}$ \\
\hline \multirow[t]{3}{*}{ Technical } & $\begin{array}{l}1 \text { Technology } \\
\text { efficiency }\end{array}$ & $\begin{array}{l}\text { Using very inefficient } \\
\text { technologies to facilitate } \\
\text { cleaner energy access }\end{array}$ & $\begin{array}{l}\text { Using inefficient } \\
\text { technologies to } \\
\text { facilitate cleaner } \\
\text { energy access }\end{array}$ & $\begin{array}{l}\text { Using moderately efficient } \\
\text { technologies to facilitate } \\
\text { cleaner energy access }\end{array}$ & $\begin{array}{l}\text { Using high efficiency } \\
\text { technologies to facilitate cleaner } \\
\text { energy access }\end{array}$ & $\begin{array}{l}\text { Using very high efficiency } \\
\text { technologies to facilitate } \\
\text { cleaner energy access }\end{array}$ \\
\hline & 2 Technology maturity & $\begin{array}{l}\text { Technologies and } \\
\text { appliances are under basic } \\
\text { technology research level } \\
\text { and not available for the } \\
\text { intervention }\end{array}$ & $\begin{array}{l}\text { Technologies and } \\
\text { appliances are at the } \\
\text { level of technology } \\
\text { demonstration and are } \\
\text { not easily available for } \\
\text { the intervention }\end{array}$ & $\begin{array}{l}\text { The selected technology of } \\
\text { the intervention is } \\
\text { operational level and } \\
\text { achieves widespread } \\
\text { adoption in part of the target } \\
\text { region/country }\end{array}$ & $\begin{array}{l}\text { The selected technology of the } \\
\text { intervention is relatively mature } \\
\text { and achieves widespread } \\
\text { adoption in part of the target } \\
\text { region/county }\end{array}$ & $\begin{array}{l}\text { The selected technology of } \\
\text { the intervention is mature } \\
\text { and achieves widespread } \\
\text { adoption in the target } \\
\text { region/county }\end{array}$ \\
\hline & $\begin{array}{l}3 \text { Technology } \\
\text { replicability and } \\
\text { scaling-up }\end{array}$ & $\begin{array}{l}\text { No possibility for scaling- } \\
\text { up or replicability }\end{array}$ & $\begin{array}{l}\text { Small possibility of } \\
\text { scaling-up and } \\
\text { replicability }\end{array}$ & $\begin{array}{l}\text { Medium possibility of } \\
\text { scaling-up and replicability }\end{array}$ & $\begin{array}{l}\text { High possibilities of scaling-up } \\
\text { but cannot be replicated to other } \\
\text { regions/countries }\end{array}$ & $\begin{array}{l}\text { High possibilities of scaling- } \\
\text { up and replicability to other } \\
\text { regions/countries }\end{array}$ \\
\hline \multirow[t]{3}{*}{ Environmental } & 1 Ecological stress & $\begin{array}{l}\text { Ecosystem is ruined by the } \\
\text { intervention }\end{array}$ & $\begin{array}{l}\text { The intervention } \\
\text { induces high stress and } \\
\text { has a large impact on } \\
\text { local ecosystem }\end{array}$ & $\begin{array}{l}\text { The intervention induces } \\
\text { some stress and has some } \\
\text { impact on local ecosystem }\end{array}$ & $\begin{array}{l}\text { The intervention induces } \\
\text { minimal stress and impact on } \\
\text { local ecosystem }\end{array}$ & $\begin{array}{l}\text { The Intervention protects the } \\
\text { ecosystem without any stress } \\
\text { on it }\end{array}$ \\
\hline & $\begin{array}{l}2 \text { Greenhouse } \\
\text { Gas(GHG) emissions }\end{array}$ & $\begin{array}{l}\text { The GHG emissions } \\
\text { increase due to } \\
\text { intervention, for instance, } \\
\text { using conventional fossil } \\
\text { fuel }\end{array}$ & $\begin{array}{l}\text { The intervention does } \\
\text { not reduce or increase } \\
\text { GHG emissions }\end{array}$ & $\begin{array}{l}\text { The intervention reduces } \\
\text { GHG emissions by a small } \\
\text { amount }\end{array}$ & $\begin{array}{l}\text { The intervention reduces GHG } \\
\text { emissions by a medium amount }\end{array}$ & $\begin{array}{l}\text { The intervention significantly } \\
\text { reduces GHG emissions }\end{array}$ \\
\hline & $\begin{array}{l}3 \text { Air, land and water } \\
\text { quality }\end{array}$ & $\begin{array}{l}\text { As a result of the } \\
\text { intervention, a great } \\
\text { amount of pollutants are } \\
\text { emitted to air, land and } \\
\text { water, and serious negative } \\
\text { effects are observed }\end{array}$ & $\begin{array}{l}\text { The intervention has } \\
\text { some negative impact } \\
\text { on air, land and water } \\
\text { quality, which threaten } \\
\text { the availability of such } \\
\text { resources }\end{array}$ & $\begin{array}{l}\text { The intervention has minimal } \\
\text { negative impact on air, land } \\
\text { and water quality }\end{array}$ & $\begin{array}{l}\text { The intervention has no negative } \\
\text { impact on air, land and water } \\
\text { quality }\end{array}$ & $\begin{array}{l}\text { The intervention improves } \\
\text { the air, land and water } \\
\text { quality of local area }\end{array}$ \\
\hline
\end{tabular}


Based on the above, we evaluate indicator performance according to the Likert scale. This operates according to five levels: $1=$ very poor, $2=$ poor, $3=$ fair, $4=\operatorname{good}$, and $5=$ very good (Allen and Seaman, 2007). A score of 5 is tantamount to the 'best practice'. Working backwards from 5, scores reflect an ever-decreasing resemblance to the best practice, and 1 implies a negative effect under each dimension, i.e. that the stated intervention resulted in an observable decline, for the given indicator.

Table 1 shows the full list of indicators along with the possible values they can take depending on their performance. It is important that the evaluation is consistent across the different initiatives, therefore each score (1-5) is accompanied by an explanatory note.

\subsection{Weighting}

Indicators are weighted to show their relative importance to the evaluating party. The higher the weight the more important the indicator is considered to be, in this case, to the effectiveness of Energy Access Intervention. The weights indicate how much each indicator matters, in other words, how much higher the value of one indicator needs to be in order to compensate for a lower value of another indicator.

Weights can be assumed equal if all the analysed indicators have equal importance. For example, we assume weights of all dimensions equal for the purposes of this study (social, political, financial, environmental, and technical). Otherwise weights can be allocated using participatory methods such as budget allocation evaluation, or statistical methods (e.g. data envelopment analysis, factor analysis). Statistical models are used to determine the weights in such a way that would place greater importance on the indicators where better quality data is available, and to account for possible correlations. In our case it is important to ensure that the weights reflect the stakeholder views and priorities, which is best determined by participatory methods. Moreover, the way we define indicator scoring means that the data quality is uniform among different indicators. Therefore, we used a participatory method to define weights of indicators within each dimension.

Providing a weighting for the five dimensions themselves was beyond the scope of the study and hence the five dimensions are assumed to be equally important (similar assumption is used in calculation of HDI (UNDP, 2013).The indicators within each dimension were 
analysed separately, as some may be more or less important to how successful an intervention is from the point of view of that dimension (e.g. social). This means that a budget of 100 points was given to each dimension and experts were asked to allocate them among the indicators based on their experience and judgement of their relative importance as to how successful an EAI is. The overall weight for each indicator was obtained by averaging all expert responses and scaled so that: $\sum_{i} w_{i}^{j}=1$, for each dimension $\mathrm{j}$, where " $i$ " are indices within the dimension.

To obtain expert opinions regarding the relative importance of each indicator, a questionnaire was designed and sent to the GNESD contacts list, as well as staff at the UNEP DTU Partnership. A total of 10 answers were obtained. The weighting exercise could be further improved by expanding the expert group, and ensuring they have a good understanding of the context, which was not necessarily known to all the experts in detail. The results of the weighting step are shown in Table 2.

Table 2: Results of the weighting exercise (average of 10 expert contributions)

\begin{tabular}{|c|c|c|}
\hline Dimension & Indicator & Weight \\
\hline \multirow[t]{3}{*}{ Social } & $\begin{array}{l}\text { Social progress/benefit in local community and } \\
\text { region from an intervention }\end{array}$ & 0.42 \\
\hline & $\begin{array}{l}\text { Contribution to local productive activities/job } \\
\text { creation }\end{array}$ & 0.39 \\
\hline & Public attitude to the intervention & 0.19 \\
\hline \multirow[t]{3}{*}{ Political } & Political environment and energy targets & 0.37 \\
\hline & Effective local energy institution or equivalent & 0.34 \\
\hline & $\begin{array}{l}\text { Transparent and accountable multi-stakeholder } \\
\text { process utilized in current policy formulation }\end{array}$ & 0.29 \\
\hline \multirow[t]{3}{*}{ Financial } & Co-financing structure & 0.28 \\
\hline & Proportion of combination of end-user financing & 0.27 \\
\hline & Sustainable financing mechanism & 0.45 \\
\hline \multirow[t]{3}{*}{ Technical } & Technology efficiency & 0.36 \\
\hline & Technology maturity & 0.32 \\
\hline & Technology replicability and scaling-up & 0.32 \\
\hline \multirow[t]{3}{*}{ Environmental } & Ecological stress & 0.35 \\
\hline & Greenhouse Gas(GHG) emission & 0.25 \\
\hline & Air, land and water quality & 0.40 \\
\hline
\end{tabular}




\subsection{Aggregation}

To calculate the final composite index of energy access interventions, the 5 dimension indices need to be calculated and subsequently all dimensions aggregated into one final index (Energy Access Best Practice Index). Aggregation methods can be categorised into linear, geometric, and non-compensatory multi-criteria approaches (OECD and JRC, 2008). Both geometric and linear approaches rely on the assumption that weights express trade-offs between indicators (deficit in one dimension can be compensated by surplus in another). Multi-criteria approaches are suitable if this assumption is considered unreasonable, particularly where individual indicator values are quantitative rather than qualitative, and where very different dimensions need to be aggregated. To use non-compensatory approaches, it is necessary to have a full set of countries, initiatives, etc. to be evaluated at the time of analysis. In our analysis, we do not consider non-compensatory approaches because:

1. The values of indicators are all expressed qualitatively, and the data format is uniform

2. The indicator for Quality (with reference to "best practice") of Energy Access Interventions should be relatively simple to use and easy to calculate for any newly completed EAI.

Therefore we assume that the disadvantages in one dimension or indicator can be compensated by better performance in another. In order for these methods to give a meaningful final index, it is also necessary for there to be no conflict or synergy among indicators. The choice between linear and geometric aggregation depends on the perspective of how much reward a better performance should receive. Linear aggregation rewards subindicators in direct proportion to the weights, which implies full compensability. Meanwhile geometric aggregation gives higher reward to better scores, and "punishes" low scores. The linear composite indicator value for a particular incentive would be calculated as:

$$
C I=\sum_{i=1}^{N} w_{i} * P_{i}
$$

Equation 1

Meanwhile the geometrically aggregated composite indicator is expressed below: 


$$
C I=\prod_{i=1}^{N} P_{i}^{w_{i}}
$$

Equation 2

Here $\mathrm{N}$ is the number of sub-indicators, $\mathrm{w}_{\mathrm{i}}$ are weights for each indicator, and $\mathrm{P}_{\mathrm{i}}$ are scores (performance values) for each indicator.

In our case we need to decide how to aggregate indicators within each dimension, and then how to aggregate the dimensions themselves. That is, as a first step, we need to calculate Social, Political, Financial, Technical and Environmental indices for an intervention, and secondly to obtain a single value by combining all these dimensions. We argue that the use of a geometric aggregation in both steps would be more appropriate, as it rewards more balanced incentives, rather than those that are particularly good in one aspect and lacking in another. This is important both within and between dimensions. Therefore our proposed procedure for calculating the Energy Access Intervention Quality Index consists of two steps:

Step 1. Calculate dimensional indices for each dimension $\mathrm{j}$, given weights $\mathrm{w}_{\mathrm{ij}}$ and scores $\mathrm{P}_{\mathrm{ij}}$ for dimension $\mathrm{j}$ and index $i$ within the dimension:

$$
I_{j}=\prod_{i=1}^{3} P_{i j}^{w_{i j}}
$$

Equation 3

Step 2. Combine the dimensional indices into the overall Composite Energy Access Intervention Quality Indicator:

$$
C E A I Q=\prod_{j}^{5} I_{j}^{\frac{1}{5}}
$$

Equation 4

It is important to ensure that all performance values are strictly positive. When geometric aggregation is used, raw indicator values can be used as normalised values. Due to the scale used to evaluate performance, this is preferable as it will avoid values going down to zero. In this way an intervention that is deemed to follow "best practice” will result in an EAI value of 5. All the sub-indices will also have values of 5 . An example of valuation using this procedure and alternative options will be discussed using case studies in section 3 . 


\subsection{Visualisation}

The pentagonal diagram provides a visual representation of the level of development under each dimension. The central point of the pentagon, where the lines meet, symbolizes a negation of the best case scenarios, while the outer perimeter represents the 'best practice' (Figure 1).

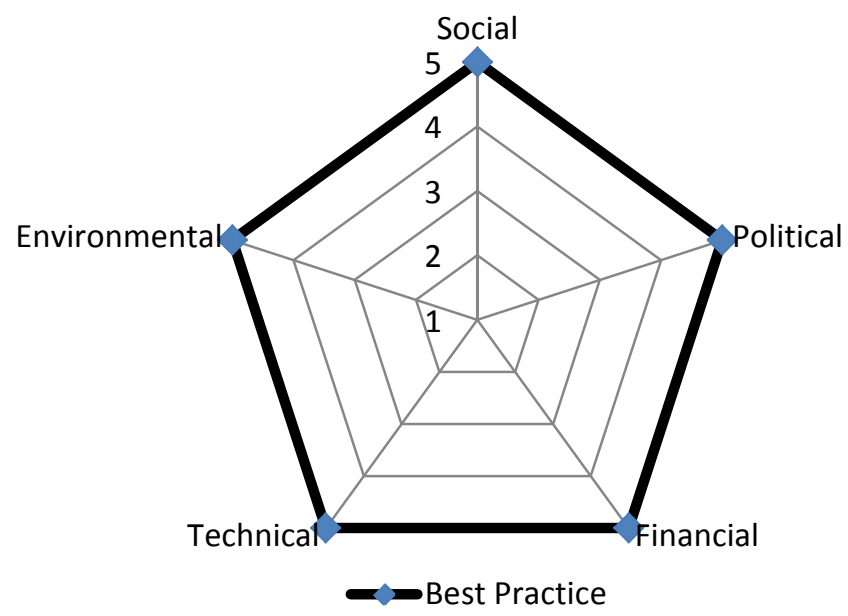

Figure 1: The pentagon of an ideal ('best practice’) energy access intervention

\subsection{Constraints and Assumptions}

There are a number of assumptions and constraints surrounding energy access issues that need to be identified and discussed.

\section{Energy services categories}

The case study material available in the GEAKB refers mainly to electrification and modern cooking solutions, on which enough documented evidence is available. Therefore, to simplify this study, mechanical power will not be taken into consideration, and so the whole study is a measurement of access to electricity and cooking solutions as the key means to achieve universal modern energy access.

\section{Implementation level}


Following the description provided by SE4ALL, the levels of EEAI range from global to regional and then to national (Birol and Brew-Hammond, 2012). However, in the present study, we only operate at the global scale to clarify and make robust the concept of "best practice”, meaning that some specific national indicators are not taken into account.

\section{Targeted Areas}

Due to the multi-tier nature of energy access, it is essential to estimate the baseline of access to energy services before specific interventions can be evaluated. The approach taken by the UN Secretary General's Advisory Group on Energy and Climate Change (AGECC) illustrates that access is often an incremental process starting with a focus on servicing basic human needs, but needs to move further to create a self-sustaining process based on local economic development (Christensen et al., 2012). In this study we focus on interventions that target Level 1 energy access (basic human needs).

\section{Data collection}

The case studies used to test the best practice framework are taken from the GNESD Energy Access Knowledge Base (GEAKB). The GEAKB includes information about policies, projects or programmes which aim to enhance the access to energy services for poor households, communities or small-scale businesses. The GEAKB was developed by the UNEP DTU Partnership as a means to share detailed energy access case studies, initially provided by the 10 GNESD member centres that followed a predefined template. The template requires both quantitative and qualitative data concerning project objectives, outputs, barrier analyses, successes, failures, lessons learned, etc. This information is targeted at policy makers, project developers and other database users, providing a quick and simple overview of the intervention. Although the GEAKB aims to draw upon transparent and verifiable data, the case studies require additional information that is not always available in the GEAKB. In particular for the dimension of environment, most of the cases in GEAKB do not have sufficient information for the stated indicators and hence further sources, including official documents and 'grey literature', were drawn upon.

\section{Case studies}


In order to test the best practice framework, it must be applied at the operational level, i.e. against specific case studies of energy access interventions. We conducted an example valuation, against case studies from China, Bangladesh and Nepal.

\subsection{Case study descriptions}

Three interventions were selected as case studies: Sending electricity to towns (SDDX, China), Biomass Briquetting Technology: Domestic and Small Industrial (BBDS, Bangladesh), and Micro-Hydro Village Electrification in Nepal (MHVE, Nepal) (GNESD, 2013a; GNESD, 2013c). Generally, the energy service needs are at the level of basic human needs for these three cases.

\section{Sending Electricity to Towns (Song Dian Dao Xiang - SDDX)}

The Sending Electricity to Towns project was designed with the aim of providing renewable energy-based electricity to rural remote areas. The SDDX project was launched in 2002 by the National Development and Reform Commission, aiming at providing electricity to around 200,000 households in 1,061 towns without grid connection (Gao and Zhao, 2006). SDDX was implemented in 12 provinces including Gansu, Hunan, Inner Mongolia, Shaanxi, Sichuan, Yunnan, Xinjiang, Qinghai and Tibet. The total investment amounted to RMB 4.7 billion, of which 2.96 billion were funded by loans issued by the central government and the rest were from local governments (PMO, 2005). The SDDX programme was one of the largest rural electrification projects in the world that combined small hydro, solar PV and wind power technologies. Between 2002 and 2004, 275 MW of small hydropower systems were installed in more than 300 townships (Stroup, 2006).

Biomass Briquetting Technology for Domestic and Small Industrial uses (BBDS)

This project focused on building local capacities to design and construct an efficient briquetting machine and stove for small scale commercial and residential applications. Rice husk residue was used as a more sustainable alternative raw material for fuel briquettes than wood fuel and which, with improvements in the briquetting technology, has become more cost effective than traditional wood fuels (Bhattacharya, 2002). The project was part of the "Renewable Energy Technologies in Asia” programme, funded by Swedish International 
Development Cooperation Agency (Sida), coordinated and implemented by various Asian countries between 1996-2003, including Bangladesh (Bhattacharya et al., 2002).

\section{Micro-Hydro Village Electrification in Nepal (MHVE)}

The Micro-hydro Village Electrification in Nepal (MHVE) is widely regarded as the most effective component of Nepal Power Development Project (NPDP), having distributed more than 250 micro-hydro units, supplying 50,000 households in less than ten years, despite significant technical, economic, political, and social challenges (Sovacool et al., 2011a). The project was carried out as part of a national strategy through the Rural Energy Development Programme (REDP) that was funded by the Government of Nepal and multilateral donors including the World Bank (Sovacool at al., 2011b).The micro-hydro systems provided continuous electricity to end users, based on a mini-grid system.

\subsection{Case study results}

Each intervention was evaluated by the authors against the set of indicators defined in Section 2.1, based on the information provided in the GEAKB. The weights for each indicator were also arrived at through the survey given to specialists, as described in Section 2.4. Table 3 summarizes the results of the evaluation and expert surveys on the SDDX, BBDS, and MHVE programmes.

\section{Table 3: Results of case study evaluations}

\begin{tabular}{llllll}
\hline Dimension & Indicator & $\begin{array}{l}\text { Relative } \\
\text { weight within } \\
\text { dimension }\end{array}$ & SDDX & BBDS & MHVE \\
\hline Social & $\begin{array}{l}\text { Social progress/benefit in local community and } \\
\text { region from an intervention } \\
\text { Contribution to local productive activities/job } \\
\text { creation }\end{array}$ & 0.42 & 5 & 4 & 5 \\
& Public attitude to the intervention & 0.40 & 5 & 5 \\
& Political environment and energy targets & 0.37 & 5 & 5 \\
\hline Political & Effective local energy institution or equivalent & 0.34 & 5 & 2 & 5 \\
& Transparent and accountable multi-stakeholder & 0.30 & 3 & 4 \\
& process utilized in current policy formulation & & 4 & 5 \\
\hline Financial & Co-financing structure & 0.29 & 5 & 2 & 5 \\
& Proportion of combination of end-user financing & 0.27 & 4 & 4 & 4 \\
& Sustainable financing mechanism & 0.45 & 4 & 5 & 4 \\
\hline Technical & Technology efficiency & 0.36 & 4 & 5 & 3 \\
& Technology maturity & 0.33 & 4 & 4 & 4
\end{tabular}




\begin{tabular}{llllll} 
& Technology replicability and scaling-up & 0.32 & 4 & 5 & 5 \\
\hline Environmental & Ecological stress & 0.35 & 4 & 4 & 4 \\
& Greenhouse Gas(GHG) emission & 0.25 & 4 & 4 & 5 \\
& Air, land and water quality & 0.40 & 4 & 5 & 5 \\
\hline
\end{tabular}

Following the established algorithm, the first step is the calculation of combined scores for each dimension, using Equation 3. As the weights of dimensions are assumed equal, the simple geometric mean is calculated to obtain the values of the overall Composite Indicator of quality of these interventions. The results of this procedure are shown in Table 4.

Table 4: Calculated indices for the 3 case studies

\begin{tabular}{llll}
\hline Dimension & SDDX & BBDS & MHVE \\
\hline Social & 5 & 4.6 & 5 \\
Political & 3.6 & 2.8 & 4.6 \\
Financial & 4.3 & 3.6 & 4.3 \\
Technical & 4.0 & 4.7 & 3.9 \\
Environmental & 4.0 & 4.4 & 4.6 \\
\hline Overall CEAIQ & $\mathbf{4 . 1 5}$ & $\mathbf{3 . 9 4}$ & $\mathbf{4 . 4 6}$ \\
\hline Rank & 2 & 3 & 1 \\
\hline
\end{tabular}

The combined index allows for a direct and quick comparison of how well each energy access intervention performs, and how they compared with the ideal ("best practice") performance.

In order to visualise these scores, the values $I_{j}$ calculated in step 1 are plotted in Figure 2, where each vertex refers to one of the five dimensions: social, political, financial, technical, and environmental. 


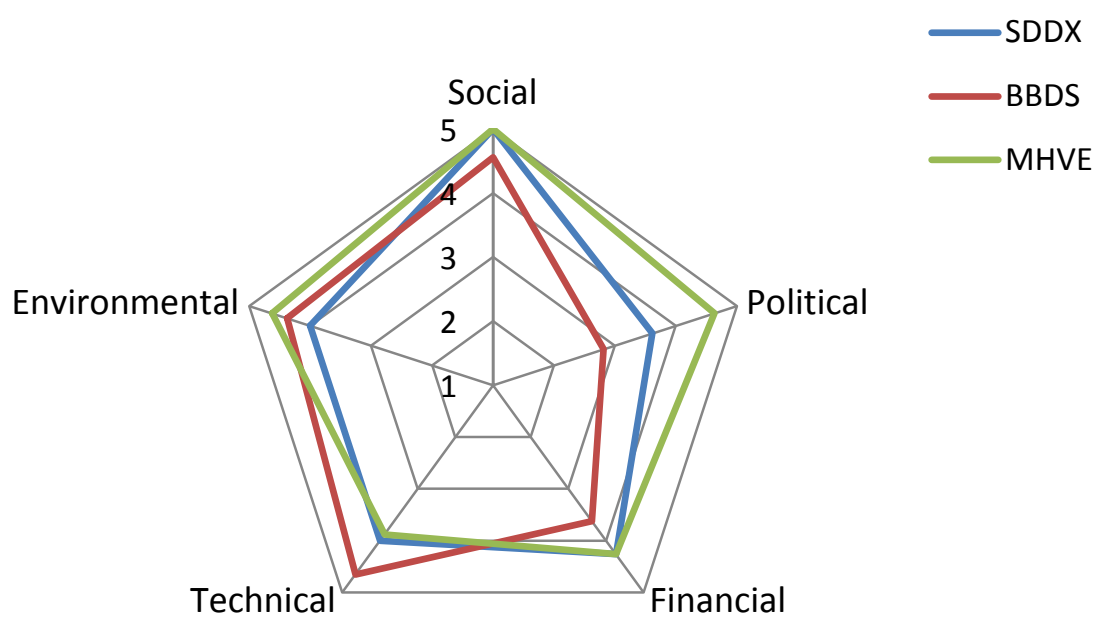

Figure 2: Visual representation of dimension indices

\subsection{Ranking dependence on aggregation method choice}

We have calculated the alternative values for each case study using linear aggregation (LA) method for step 1, step 2 or both. For these case studies, using LA did not change the ranking. The difference in the indicator value was most pronounced for BBDS study, using LA resulting in values more uniform among all the studies, while using geometric aggregation distinguishes them more.

\section{Discussion and conclusions}

While the calculated results were broadly similar across the case studies, the MHVE programme appeared closest to the ideal or 'best practice' scenario, with the overall Quality Index of 4.5. In the language of 'best practice', the SDDX programme shows the highest development in its social achievements (5.00) and the lowest is the score in the political dimension (3.6). The BBDS project yields lower values than two other cases across all dimensions apart from 'technical', where is scores the highest among the three cases. The MHVE programme performs best in the social and political dimensions. In general, the greatest and most uniform benefits of the three cases can be noted in the social dimension. That is, these three cases have had a strong positive effective on social progress, job creation and social acceptance, strengthening social capital, promoting mobility and the increased well-being of rural households. On the other hand, there are significant gaps between the 'political' category performances of the three cases. Notably, the MHVE programme scores 
highest in the political dimension, as a result of having created an enabling policy environment, backed by strong government commitment, effective cooperation between local institutions and active local participation. In the Chinese SDDX programme, the political dimension received a low score, mainly resulting from institutional barriers.

Though there have been many attempts to develop platforms or approaches to measure the degree of energy access in various scales, or to create different models and propose algorithms for selecting energy technologies, the 'best practice' concept has not, prior to this study, been operationalized for EAIs. The development and application of a multidimensional framework is a simple but comprehensive tool to evaluate EAIs by employing a synthesis of aggregate individual indicators. The composite score of an intervention shows a performance level, rather than setting a goal.

This paper has presented a framework to develop and apply the concept of 'best practice' for EAIs. As a result of the complexity and multidimensionality of EAIs, it is important to establish what has worked and what are the barriers facing a specific intervention. Thus, the methods for measuring and monitoring are essential for tracking progress and achieving accountability. Our framework for 'best practice' simplifies the process of characterising and comparing EAIs, across a range of dimensions and contexts. The framework could be used to promote the best practice concept for energy access project planning and implementation, and it is thought that this study will be of value to policy-makers and development practitioners in the field of EAIs. To further understand the value and strengths of the framework, helpful first steps would be: to conduct a sensitivity analysis on the weights, broadening the sample of tested case studies, and checking the effect of aggregation methods, and other assumptions, on the observed results.

Reflecting more broadly on the value of efforts to develop best practice frameworks for project-based interventions, the methodology presented in this article highlights the inherent challenges and limitations to developing a 'one-size-fits-all' approach. By extension, we can observe tensions between the oft-stated desire by governments and OECD development agencies to refer to objective, absolute, measures of best practice, and the highly contextual realities within which specific projects are designed and implemented. The desire for comparable best practice data is also undermined by the common lack of baseline data, especially in less developed countries. However, the approach detailed in this article does 
offer a comparative means to highlight the relative strengths and weaknesses of any given project, informed by a mix of quantitative and qualitative data, which enables both ex-post assessments and project learning. This makes it a useful tool for both policy makers and project designers, applicable to different sector and aspects of sustainable development. 


\section{References}

AGECC 2010. Energy for a sustainable future. New York.

Allen, I. E., Seaman, C. A. 2007. Likert scales and data analyses. Quality Progress, 40, 64-65.

Bazilian, M., Nussbaumer, P., Cabraal, A., Centurelli, R., Detchon, R., Gielen, D., Rogner, H., Howells, M., McMahon, H. \& Modi, V. 2010. Measuring energy access: Supporting a global target. Earth Institute, Columbia University, New York.

Bhattacharya, S. C., Leon, M. A. \& Rahman, M. M. 2002. A study on improved biomass briquetting. Energy for Sustainable Development, 6, 67-71.

Bhattacharya, S. C. 2002. Renewable energy for Asia research and dissemination of selected technologies. Renewable Energy World 28, 2367.

Bhattacharya, S. C. 2012a. Energy access programmes and sustainable development: A critical review and analysis. Energy for Sustainable Development, 16, 260-271.

Bhattacharya, S. C. 2012b. Review of alternative methodologies for analysing off-grid electricity supply. Renewable and Sustainable Energy Reviews, 16, 677-694.

Birol, F. 2010. World energy outlook 2010. International Energy Agency.

Birol, F., Brew-Hammond, A. 2012. Sustainable energy for all. Technical report of task force 1 in support of the objective to achieve universal access to modern energy services by 2030.

CCF (no date). Identifying and Promoting Promising Practices. Intermediary Development Series. Compassion Capital Fund.

Christensen, J. M., Mackenzie, G. A., Pedersen, M. B. 2012. Enhancing access to electricity for clean and efficient energy services in Africa. UNEP Risø Centre.

Ekouevi, K. \& Tuntivate, V. 2011. Household Energy Access for Cooking and Heating: Lessons Learned and the Way Forward. Energy and Mining Sector Board Discussion Paper.

ESMAP 2012. Innovative approaches to energy access for the urban poor: Summaries of Best Practices from cases studies in Four countries, Washington DC, USA.

Fransen, T., McMahon, H. \& Nakhooda, S. 2008. Measuring the way to a new global climate agreement. World Resources Institute Discussion Paper. Washington, DC: World Resources Institute.

Fuso Nerini, F., Howells, M., Bazilian, M., Gomez, M. F. 2014. Rural electrification options in the Brazilian Amazon: A multi-criteria analysis. Energy for Sustainable Development, 20, 36-48.

Gao, H., Zhao, Y.-Q. 2006. Investigation and analysis on household electric power consumption and demand in " Song Dian Dao Xiang" Project Renewable Energy 127, 3.

GEA 2012. Global Energy Assessment - Toward a Sustainable Future. Cambridge University Press, Cambridge UK and New York, NY, USA and the International Institute for Applied Systems Analysis. Laxenburg, Austria.

GNESD 2013a. Biomass Briquetting Technology: Domestic and Small Industrial Applications [Online]. Available: http://energyaccess.gnesd.org/index.php?option=com content\&view=article\&id=166:biomass-briquettingtechnology-domestic-and-small-industrial-applications\&catid=3:projects\&Itemid=24 [Accessed September 2013].

GNESD 2013b. GNESD Energy Access Knowledge Base [Online]. Available: http://energyaccess.gnesd.org/ [Accessed September 2013].

GNESD 2013c. Micro-Hydro Village Electrification in Nepal [Online]. Available: http://energyaccess.gnesd.org/index.php?option=com_content\&view=article\&id=165:micro-hydrovillage-electrification-in-nepal\&catid=3:projects\&Itemid=24 [Accessed September 2013].

Gómez, M. F., Silveira, S. 2010. Rural electrification of the Brazilian Amazon - Achievements and lessons. Energy Policy, 38, 6251-6260.

IAEA 2005. Energy indicators for sustainable development: guidelines and methodologies, International Atomic Energy Agency.

IEA 2011. Energy for all: Financing access for the poor.

IEA 2012. World Energy Outlook 2012.

Ilskog, E. 2008. Indicators for assessment of rural electrification-An approach for the comparison of apples and pears. Energy Policy, 36, 2665-2673. 
Ilskog, E., Kjellström, B. 2008. And then they lived sustainably ever after?-Assessment of rural electrification cases by means of indicators. Energy Policy, 36, 2674-2684.

Jones, R. H. 2010. Energy Poverty: How to make modern energy access universal? Special early excerpt of the World Energy Outlook.

Joseph, M. 2011. From Self Sustaining to Self-Propelling :A study of business models for energy access in developing markets IVM Institute for environmental studies.

OECD \& JRC 2008. Handbook on constructing composite indicators: methodology and user guide. OECD publishing.

Ostojic, D., Jammi, R., Barnes, D., Sanghvi, A., Mathur, S., Zhang, Y. \& Durix, L. 2011. One goal, two paths : achieving universal access to modern energy in East Asia and the Pacific. . Washington, DC: World Bank.

Pachauri, S. 2011. Reaching an international consensus on defining modern energy access. Current Opinion in Environmental Sustainability, 3, 235-240.

Paul, E. 2008. Validating best practices. Industrial Engineer, 40, 20.

PMO 2005. SDDX PROGRAM Survey and Recommendation. PMO of NDRC/UNDP/GEF Speed-up of Chinese Renewable Energy Commercialization and Capacity Bulding.

Practical Action 2009. Energy poverty: the hidden energy crisis. Rugby, UK.

Practical Action 2010. Poor people's energy outlook 2010 Rugby, UK.

Practical Action 2012. Poor people's energy outlook 2012: Energy for earning a living.

SE4ALL 2012. Sustainable Energy for all: Global tracking framework

Shyu, C.-W. 2010. Renewable energy policy in remote rural areas of Western China: Implementation and socio-economic benefits. Bonn, Univ., Diss., 2010.

Snyder, S. R., Favoretto, A. M., Baetz, R. A., Derzon, J. H., Madison, B. M., Mass, D., Shaw, C. S., Layfield, C. D., Christenson, R. H., Liebow, E. B. 2012. Effectiveness of practices to reduce blood culture contamination: A Laboratory Medicine Best Practices systematic review and meta-analysis. Clinical Biochemistry, 45, 999-1011.

Sovacool, B. K., Bambawale, M. J., Gippner, O., Dhakal, S. 2011a. Electrification in the Mountain Kingdom: The implications of the Nepal Power Development Project (NPDP). Energy for Sustainable Development, 15, 254-265.

Sovacool, B. K., Dhakal, S., Gippner, O., Bambawale, M. 2011b. Rural energy development on the "roof of the world" lessons from Microhydro village electrification in Nepal. Singapore, Lee Kuan Yew School of Public Policy.

Stroup, K. 2006. Renewable Energy for Village Power in Bulunkou Township.

UNDP 2010. UNDP and Energy Access for the Poor: Energizing the Millennium Development Goals [Online]. Available: http://www.undp.org/content/undp/en/home/librarypage/environmentenergy/climate_change/climate_change_andpoverty/undp-and-energy-access-for-thepoor.html [Accessed September 2013].

UNDP 2011. Going Renewable- China's Success Story in Capacity Development Towards an 'Energy Plus' approach for the poor: A review of good practices and lessons learned from Asia and the Pacific, Case Study 6 Bangkok, Thailand: United Nations Development Programme, Asia-Pacific Regional Centre.

UNDP 2012. Integrating Energy Access and Employment Creation to Accelerate Progress on the MDGs in Sub-Saharan Africa

UNDP 2013. Technical notes. Human Development Report 2013. United Nations Development Programme.

Yadoo, A., Cruickshank, H. 2012. The role for low carbon electrification technologies in poverty reduction and climate change strategies: A focus on renewable energy mini-grids with case studies in Nepal, Peru and Kenya. Energy Policy, 42, 591-602. 